\title{
Penile Fracture and Early Repair Outcomes
}

\section{Penil Fraktür ve Erken Onarım Sonuçları}

\author{
Serdar Çelik, Sedat Karakoç, Ozan Bozkurt, Ömer Demir, Ahmet Adil Esen
}

\author{
Dokuz Eylül University Faculty of Medicine, Department of Urology, Izmir, Turkey
}

\section{What's known on the subject? and What does the study add?}

Early repair with degloving method is effective method in postoperative erectile success in young patients.

\begin{abstract}
Objective

In this study, we aimed to present clinical characteristics and repair outcomes in patients who had sexual intercourse-induced penile trauma and underwent early surgical repair in our clinic.
\end{abstract}

\section{Materials and Methods}

We retrospectively evaluated records of patients who underwent early surgical repair due to penile trauma between 2004 and 2014 in our clinic. Preoperative, peroperative and postoperative data were analyzed. Patient characteristics, penile trauma characteristics, pre-trauma and postoperative International Index of Erectile Function-Erectile Function Domain Scores (IIEF-ED), and operation features were evaluated.

\section{Results}

Twenty-six male patients who were admitted to the emergency room with penile trauma and underwent early surgical repair were investigated. Four patients had only dorsal vein laceration and twenty-two had corpus cavernosum rupture. Postoperative erectile dysfunction was observed in three patients (the patients were older than 45 years of age, a patients had bilateral corpus cavernosum rupture and two patients had concomitant urethral trauma). Early repair was successful (86.4\%) in the remaining 19 patients. The average erection hardness grade and IIEF-ED value were 4.75 and 28.6 before penile fracture; postoperative mean erection hardness grade and IIEF-ED value were found to be 4.2 and 24.9 , respectively ( $p>0.05)$.

\section{Conclusion}

As a result, in sexual intercourse-induced penile fracture, early repair with degloving approach is effective method in postoperative erectile success in young patients and patients with isolated unilateral fractures.

\section{Keywords}

Penile fracture, early repair, International Index of Erectile FunctionErectile Function Domain Scores, urethral injury, erectile dysfunction

\section{ÖZ}

Amaç

$\mathrm{Bu}$ çalışmada cinsel ilişki nedenli penil travması olan ve kliniğimizde erken cerrahi onarım uygulanan hastaların klinik özellikleri ve onarım sonuçlarını sunmayı amaçladık.

\section{Gereç ve Yöntem}

2004-2014 tarihleri arasında penil travma nedenli kliniğimizde erken cerrahi onarım uygulanan erkek hastalar retrospektif olarak değerlendirildi. Hastaların preoperatif, peroperatif ve postoperatif verileri incelendi. Hastaların genel özellikleri ile penil travma özellikleri, travma öncesi ve postoperatif Uluslararası Erektil Fonksiyon İndeksi-Erektil Fonksiyon Alanı Skoru (IIEF-ED) değerleri ve operasyon özellikleri değerlendirildi.

\section{Bulgular}

Penil travma nedenli acil servise başvuran ve degloving yöntemi ile erken cerrahi onarım uygulan 26 erkek hasta incelendi. Hastaların dördünde sadece dorsal ven laserasyonu, yirmi ikisinde kavernozum rüptürü mevcuttu. Üç hastada (üç hasta da 45 yaş üstüydü, birinde bilateral rüptür ve ikisinde eşlik eden üretral travma mevcuttu) postoperatif erektil disfonksiyon olduğu gözlendi. Geri kalan on dokuz hastada $(\% 86,4)$ erken onarımın başarılı olduğu saptandı. Tüm hastaların fraktür öncesi ortalama ereksiyon sertlik derecesi 4,75 ve IIEF-ED değeri 28,6 iken, postoperatif ereksiyon sertlik derecesi 4,2 ve IIEF-ED değeri 24,9 saptandı ( $p>0,05)$.

\section{Sonuç}

Sonuç olarak cinsel ilişki sonucu gelişen penil fraktürlerde degloving yöntemi ile erken onarımın genç ve izole tek taraflı fraktürlerde postoperatif ereksiyon başarısında etkili yöntem olduğu söylenebilir.

\section{Anahtar Kelimeler}

Penil fraktür, erken onarım, Uluslararası Erektil Fonksiyon İndeksi-Erektil Fonksiyon Alanı Skoru, üretral yaralanma, erektil disfonksiyon 


\section{Introduction}

Penile fracture is a rare urological emergency (1). Majority of the patients come to the emergency department immediately after the trauma and are operated for repair in a short span of time. History and clinical examination are essential for diagnosis. Detumescence, penile swelling, bruise and deformation are observed during the examination. In rare cases of uncertainty, radiological imaging methods are also used. These methods are magnetic resonance imaging (MRI), ultrasonography (US), cavernosography and urethrography (2). When penile fracture case reports are examined, penile trauma was found to be more common in Middle East and North Africa when compared to the rest of the world (3). Most of the fractures in the United States develop during the sexual intercourse as a result of dislocation of the penis from the vagina due to 'faux pas du coit' and as a result of hitting the perineum or the pubic bone $(4,5)$. In this study, we aimed to present the early repair outcomes in patients who developed penile fracture during sexual intercourse.

\section{Materials and Methods}

Male patients, who underwent early surgical repair in our clinic due to penile trauma between June 2004 and December 2014, were evaluated retrospectively. Preoperative, perioperative and postoperative data were investigated upon the review of the patient records. The patients were evaluated in terms of age, height, weight, comorbidity, type and cause of trauma, erection hardness grade during sexual intercourse, pre-trauma International Index of Erectile Function-Erectile Function Domain Score (IIEF-ED), presence of fracture at physical examination, presence of urethral trauma, location of the fracture on the penis, fracture length, operation time, postoperative erectile dysfunction, postoperative IIEF-ED value, post-repair development of penile curvature and voiding dysfunction. Preoperative and postoperative IIEF-ED scores were compared with the use of the Wilcoxon test in order to predict the repair success. Furthermore, absence of postoperative erectile dysfunction, penile curvature and voiding dysfunction was considered as early surgical success. A p value of less than 0.05 was considered statistically significant.

\section{Results}

Twenty-six male patients, admitted to the emergency service due to penile trauma, were investigated. General characteristics of the patients (age, weight, height, body mass index) are given in Table 1 . The patients applied with the complaint of hearing a sound during intercourse, development of detumescence, penile swelling and bruise. The mean time to admission of the patients was 6.4 (2-14) hours. Furthermore, three of the patients had blood in their external meatus. US was performed in two patients due to uncertainty in trauma diagnosis. The rest of the patients were diagnosed clinically. Early surgical repair was performed in all patients by using the degloving technique with incision from the circumcision scar. Physical examination and operative findings of the patients are given in Table 2. Four patients had only dorsal vein laceration without rupture of the corpus cavernosum, whereas the remaining 22 patients had rupture of the corpus cavernosum. In patients with dorsal vein laceration, dorsal vein ligation was applied following the degloving procedure. Primary repair was performed in 22 patients with a mean rupture of 16.7 (5-20) $\mathrm{mm}$ of the corpus cavernosum. While one patient had bilateral rupture of the corpus cavernosum, three of the patients had concomitant urethral injury. The mean operation time was 56.5 (30-120) minutes. Perioperative urethral catheter was inserted in all patients. The catheters were removed by the end of first day in patients without urethral injury and by the end of day 10 in those with urethral injury. Three of the patients developed erectile dysfunction postoperatively. These patients were over the age 45 ,

Table 1. General characteristics of the patients

\begin{tabular}{|l|l|}
\hline $\mathrm{n}$ & 26 \\
\hline Mean age (year) & $35.6(33-70)$ \\
\hline Mean height $(\mathrm{cm})$ & $174.5(166-180)$ \\
\hline Mean weight $(\mathrm{kg})$ & $76.5(64-95)$ \\
\hline Mean BMI $\left(\mathrm{kg} / \mathrm{m}^{2}\right)$ & $25.3(21.5-29.8)$ \\
\hline Comorbidity $(\mathrm{n})$ & 1 \\
\hline BMI: Body mass index & \\
\hline
\end{tabular}

Table 2. Physical examination and operative findings of the patients

\begin{tabular}{|l|l|}
\hline & $\mathrm{n}(26)$ \\
\hline Trauma (n, \%) & \\
Unilateral corpus cavernosum rupture & $21(84.6)$ \\
Bilateral corpus cavernosum rupture & $1(3.8)$ \\
Dorsal vein laceration & $4(15.4)$ \\
Urethral rupture & $3(11.5)$ \\
\hline Rupture side ( $\mathrm{n}, \%)$ & \\
Bilateral ventral & $1(4.5)$ \\
Right ventral & $8(36.4)$ \\
Left ventral & $4(18.2)$ \\
Right dorsal & $4(18.2)$ \\
Left dorsal & $5(22.7)$ \\
\hline Rupture localization (n, \%) & $9(40.9)$ \\
Proximal & $7(31.8)$ \\
Mid & $6(27.3)$ \\
Distal & $16.7(5-20)$ \\
\hline Rupture size (mm) & $56.5(30-120)$ \\
\hline Operation time (min.) &
\end{tabular}

Table 3. Pre-trauma and post-repair erection hardness grade and International Index of Erectile Function-Erectile Function Domain Scores values of the patients who underwent penile fracture repair

\begin{tabular}{|l|l|l|l|}
\hline & Pre-trauma & Postoperative & $p$ \\
\hline Erection hardness grade & $4.75(4-5)$ & $4.21(1-5)$ & 0.066 \\
\hline IIEF-ED & $28.56(25-30)$ & $24.86(1-30)$ & 0.144 \\
\hline
\end{tabular}

IIEF-ED: International Index of Erectile Function-Erectile Function Domain Scores 
one of them had bilateral corpus cavernosum rupture and two had concomitant urethral injury. Furthermore, penile curvature developed postoperatively in the patient with bilateral rupture, whereas none of the patients developed voiding dysfunction. Early surgery was found to be successful in nineteen of the 22 patients (86.4\%). Furthermore, while the average pre-fracture erection hardness grade of the patients was 4.75 and IIEF-ED value was 28.6, the mean postoperative erection hardness grade was found to be $4.2(1-5)$ and IIEF-ED value was 24.9 (1-30). There was no statistically significant difference between the preoperative and postoperative values ( $p>0.05$ ) (Table 3 ).

\section{Discussion}

Two different surgical repair incision methods are generally defined in penile fracture repair. These are the degloving method with the degloving incision/circumcision incision and the ventral midline incision method (2). While postoperative complications have been reported to be higher with the ventral midline incision in the literature, no statistically significant difference was found (6). The degloving method was used in all the patients in our series and our postoperative complication rates were not statistically significant and were found to be lower than those reported in the literature. When the series of 300 patients reported from Tunisia is assessed, $60 \%$ of the fractures were reported to develop during masturbation and $5 \%$ of patients had concomitant urethral injury (7), whereas the rate of bilateral rupture of 10\% has been reported and the rate of the presence of concomitant urethral ruptures was 18-38\% according to the outcomes of the studies from the United States and Canada $(1,6,8)$. When the outcomes of the studies from the Middle East countries are assessed, the success rate of early repair was found to be around 92-100\% and the self-recovery was reported down to 40\% $(9,10)$. In series from Spain, Germany-Croatia and Switzerland, the number of patients was around 9-29 and the early repair success rate was to be around $80-95 \%(11,12,13)$. In one of the recent studies, postoperative success was reported to be $65 \%$. However, in this series, ventral midline incision method was used (6). With $86.4 \%$ of early surgical success, our series seems to have similar outcomes when compared to the study, in which degloving method was applied. Our rates of bilateral corpus cavernosum and urethral rupture of $3.8 \%$, are lower than that of $11.5 \%$ reported in other series. Besides the early surgical success rate, postoperative IIEF-ED value and mean erection hardness grades also contribute to the early surgical success, when compared to the values before the fracture. One of the major results of our study is that the main factor affecting surgical success is age and the extension of the fracture when the failing patients are assessed. In penile fracture cases, it is recommended to ask about the time to admission, age and pre-trauma erection quality and to identify the extension of the corpus cavernosum rupture and the presence of concomitant urethral trauma. The patient should be advised to have early fracture repair with the degloving method and be informed on the potential development of postoperative erectile dysfunction on the basis of the findings.

\section{Conclusion}

In conclusion, early repair with the use of the degloving method is identified as an effective method for the success of postoperative erection in sexual intercourse-induced penile fracture cases. Besides the early repair, other factors contributing to surgical success are the repair technique, age of the patient, pre-fracture erection hardness grade and IIEF-ED score, bilateral corpus cavernosum rupture, and the presence of urethral injury.

\section{Ethics}

Ethics Committee Approval: Ethics committee approval was not obtained because this was a retrospective study, Informed consent: Written informed consent was not obtained from patients because this was a retrospective study.

Peer-review: Externally peer-reviewed.

\section{Authorship Contributions}

Concept: Serdar Çelik, Design: Serdar Çelik, Data Collection or Processing: Serdar Çelik, Sedat Karakoç, Analysis or Interpretation: Serdar Çelik, Ozan Bozkurt, Ömer Demir, Ahmet Adil Esen, Literature Research: Serdar Çelik, Sedat Karakoç, Ozan Bozkurt, Writing: Serdar Çelik.

Conflict of Interest: No conflict of interest was declared by the authors.

Financial Disclosure: The authors declared that this study has received no financial support.

\section{References}

1. Aaronson DS, Shindel AW. U.S. national statistics on penile fracture. J Sex Med 2010;7:3226.

2. Kamdar C, Mooppan UM, Kim H, Gulmi FA. Penile fracture: preoperative evaluation and surgical technique for optimal patient outcome. BJU Int 2008;102:1640-1644.

3. Zargooshi J. Penile fracture in Kermanshah, Iran: the long-term results of surgical treatment. BJU Int 2002;89:890-894.

4. Fergany AF, Angermeier KW, Montague DK. Review of the Cleveland Clinic experience with penile fracture. Urology 1999;54:352-355.

5. Bitker M0, Belin J, Jardin A, Chatelain C. "Faux pas du coit" with associated rupture of corpora cavernosa and urethra. Urology 1988;32:447-448.

6. Swanson DE, Polackwich AS, Helfand BT, Masson P, Hwong J, Dugi DD, Martinez Acevedo AC, Hedges JC, McVary KT. Penile fracture: outcomes of early surgical intervention. Urology 2014;84:1117-1121.

7. El Atat R, Sfaxi M, Benslama MR, Amine D, Ayed M, Mouelli SB, Chebil M, Zmerli $S$. Fracture of the penis: management and long-term results of surgical treatment. Experience in 300 cases. J Trauma 2008;64:121-125.

8. Al-Shaiji TF, Amann J, Brock GB. Fractured penis: diagnosis and management. J Sex Med 2009;6:3231-3240.

9. Zargooshi J. Sexual function and tunica albuginea wound healing following penile fracture: an 18-year follow-up study of 352 patients from Kermanshah, Iran. J Sex Med 2009;6:1141-1150.

10. El-Bahnasawy MS, Gomha MA. Penile fractures: the successful outcome of immediate surgical intervention. Int J Impot Res 2000;12:273-277.

11. Moreno Sierra J, Garde Garcia H, Fernandez Perez C, Galante Romo I, Chavez Roa C, Senovilla Perez JL, Silmi Moyano A. Surgical repair and analysis of penile fracture complications. Urol Int 2011;86:439-443.

12. Muentener $M$, Suter $S$, Hauri $D$, Sulser T. Long-term experience with surgical and conservative treatment of penile fracture. J Urol 2004;172:576-579.

13. Persec Z, Persec J, Puskar D, Sovic T, Hrgovic Z, Fassbender WJ. Penile injury and effect on male sexual function. Andrologia 2011;43:213-216. 